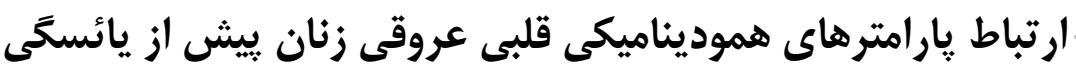

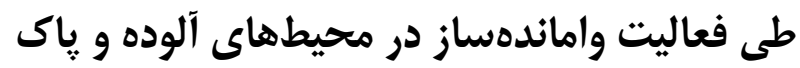

\author{
سارا يوريامهر'، ولى الله دبيدى روشن ': فريماه شيرانى'r \\ 1) كروه فيزيولوثَى ورزشى، دانشكدهُ علوم ورزشى، دانشكاه مازندرلن، بابلسر، ايران \\ م) إنجمن تحقيقات قلبى عروقى، دانشكاه علوم يزشكى (صفهان، إفهان، إيرلن
}

تاريخ دريافت:11/1/

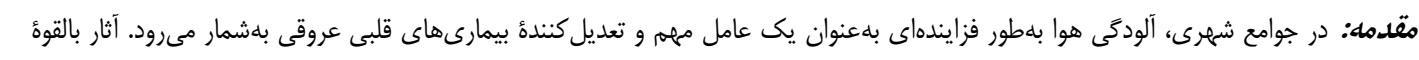

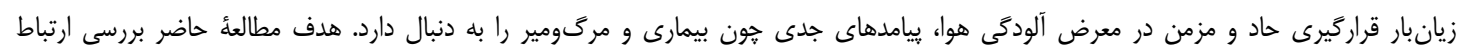

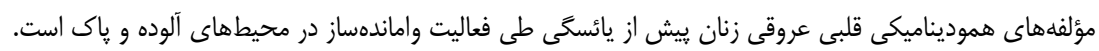

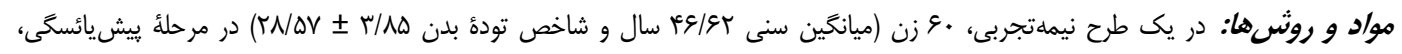

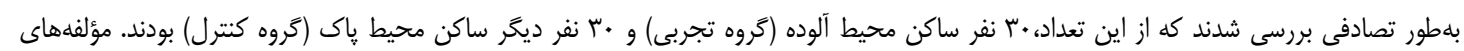

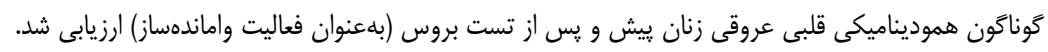

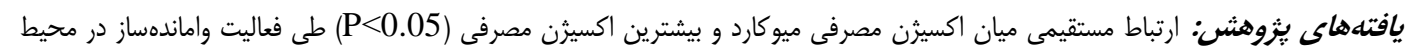

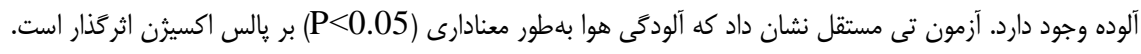

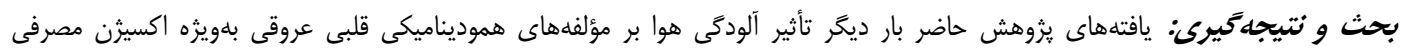

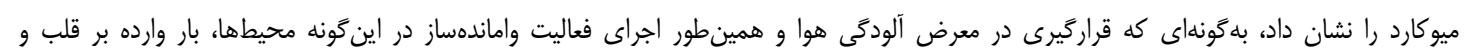

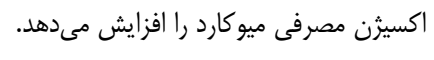

وازههاى كليدى: آلودَى هوا، يِش يائسخى، اكسيزن مصرفى ميوكارد، پالس اكسيثن، فعاليت واماندهساز

Email:vdabidiroshan@yahoo.com

Copyright () 2019 Journal of Ilam University of Medical Science. This is an open-access article distributed under the terms of the Creative Commons Attribution international 4.0 International License (https://creativecommons.org/licenses/by-nc/4.0/) which permits copy and redistribute the material, in any medium or format, provided the original work is properly cited. 
حاصلضرب فشار در ضربان (RPP)، حاصلضرب

تعداد ضربان قلب در فشارخون سيستوليك (SBP)، متغير هموديناميكى قلبى عروقى است كه بلهطور

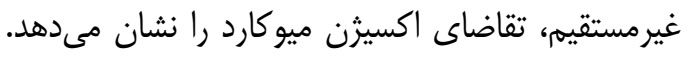
عدهاى بر اين باورند كه حاصل گسترداى براى سنجش كيفيت ياسخ هموديناميك و بار كار قلبى به ورزش است (9). اين عامل اساساً به ضربان قلب، تانسيون (كشش) سيستوليك ديوارهٔ بطنى و انقباض ميوكاردى بستخى دارد. علاوه بر اين، دورة تخليه (ED) (بازتابى از دورهٔ سيستوليك بطنى) و فشار

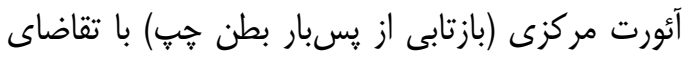

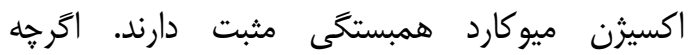

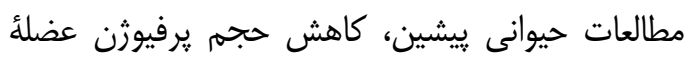
قلبى و افزايش تقاضاى اكسيثن ميوكارد را درنتيجه استشاق مونوكسيد كربن (CO) يا ذرات متراكم معلق در هوا (CAPs) نشان دادند؛ اما هيج گونه شواهد

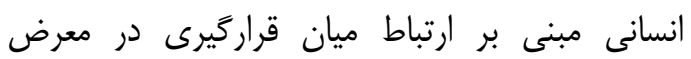
آلودگى هوا و جايخزينى عملكردى يرفيوزن ميوكارد و تقاضاى اكسيثن وجود ندارد. از سوى ديخر، شواهد گَوناگونى درباره ارتباط متقابل خاقى با التهاب عمومى ديدهشده است (• (1)؛ اما

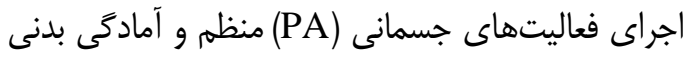
بر فرايندهاى التهابى تأثيرگذار است و كاهش خطر بروز و يا كسترش بسيارى از بيمارىها از قبيل سرطان،

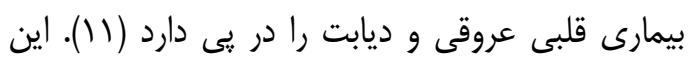

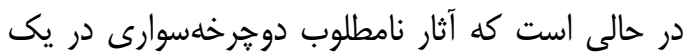
محيط با اتمسفر آلوده بر سلامت دستخاههاى گوناكون

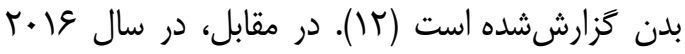

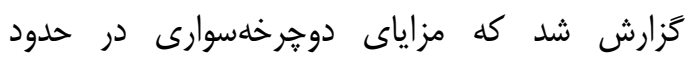

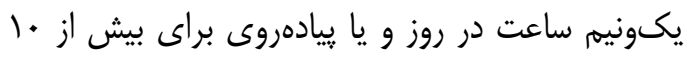

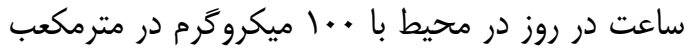
هM 2.5

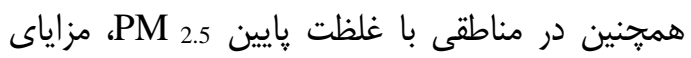

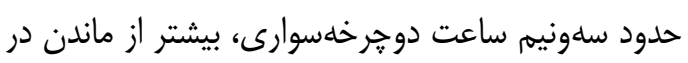

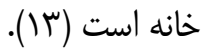
با توجه به اينكه سلامت انسان بهشدت با شرايط

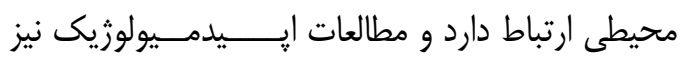

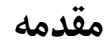

آلودَى محيطزيست بلهور عام و آلودَى هوا بلبطور خاص، در دهلهاى اخير ييامدهاى جدى مرتبط با تندرستى را در گروههاى سنى گَوناگون و بلوويزها

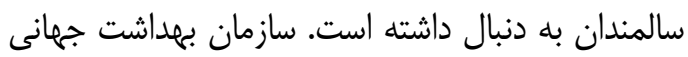

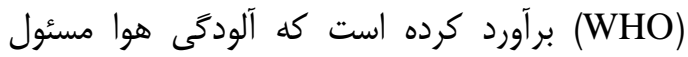
مرى زودرس ץ ميليون نفر در سال است (1).

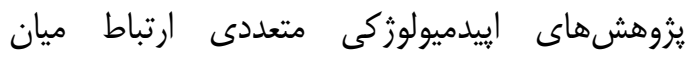

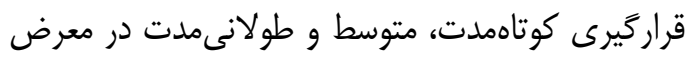
آلايندههاى هوا و افزيرى كايش ريسك ابتلا به رويداد (بيمارى)هاى قلبى عروقى از قبيل انفاركتوس ميوكارد،

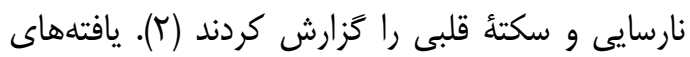

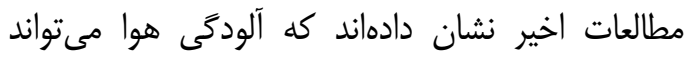

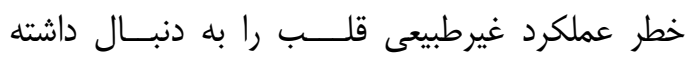

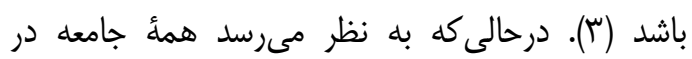
معرض خطر آلايندهاى هوا قرار دارند، برخى شواهد

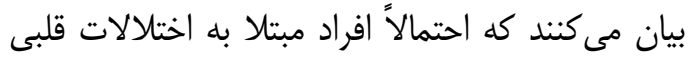

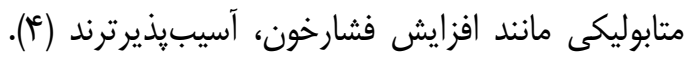
شواهد تحقيقاتى بسيارى نشان دادند كه قراركيرى

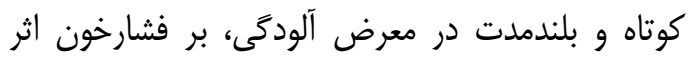

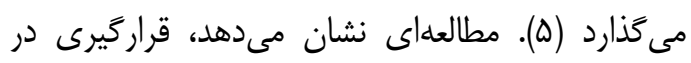
معرض آلودگى هوا ناشى از محيط كارى در در كارمندان

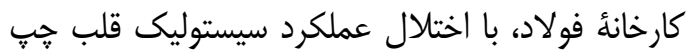

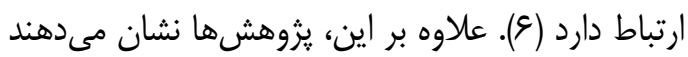

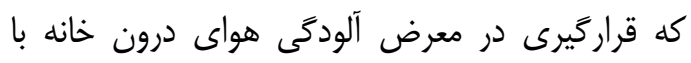

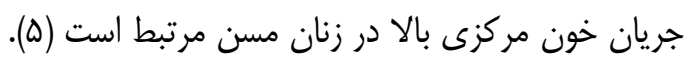
كزارش جده است كه افزايش سطوح كربن سياه (BC) سبب افزايش فشارخون سيستوليك در دوره ريكاورى

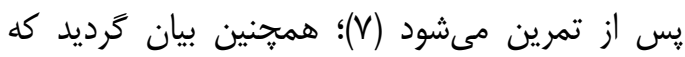

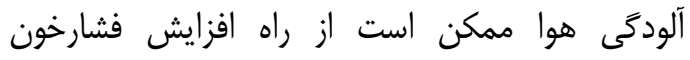

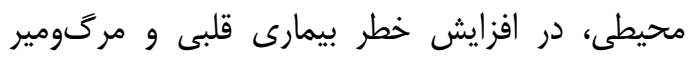
شركت داشته باشد (^). عالاوه بر اين، يزوهشهاى إنى

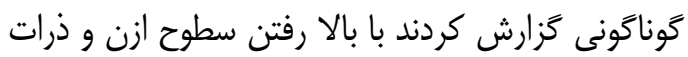

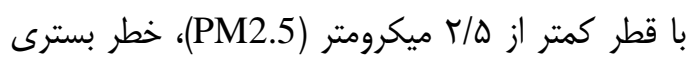

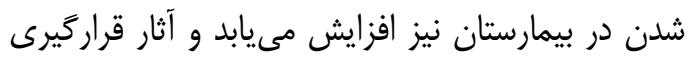

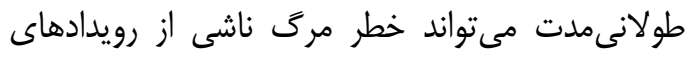
قلبى رادر طول عمر يك فرد افزايش دهد (1). 
مراحل اجراى يزوهش، بهكاركيرى تجهيزات سالم و ايمن براى اجراى يزوهش و مــحرمانه نكخه داشتن اطلاعات شخصى آنان هدايت شدند. افراد پِ إن از

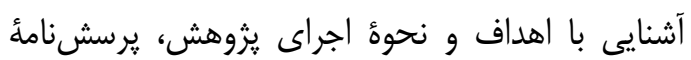

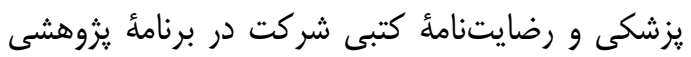
را تكميل كردند و سيس ارزيابى بالينى و كنترل متغيرهاى قلبى انجام گرفت. اين يزوهش از آبان ماه تا

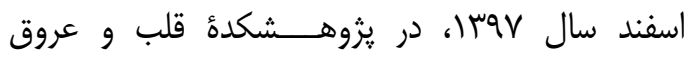
بيمارستان جمران اصفهان بركزار شد.

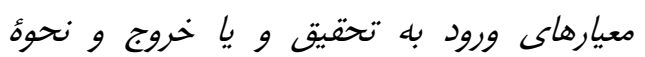
نمونهكيرى: در يزوهش حاضر تلاش گرديد از راه

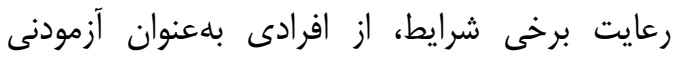

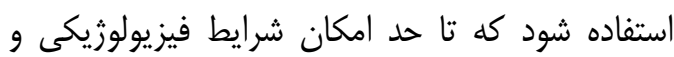

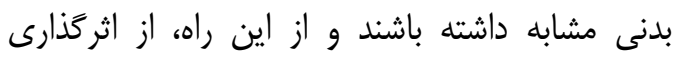
عوامل مزاحم در تحقيق جلوكيرى گردد. بعضى از

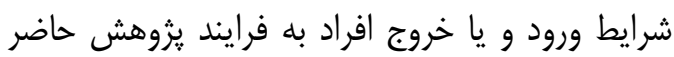

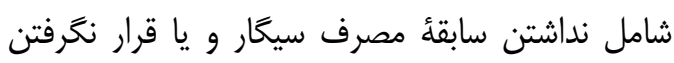

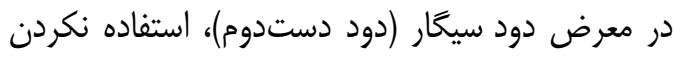

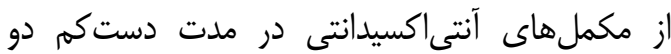

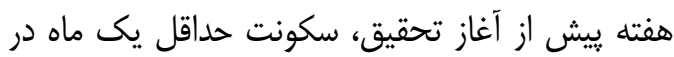

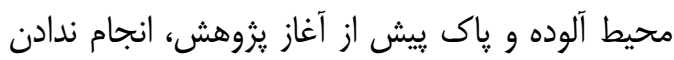

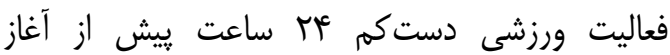
تحقيق، خواب منظم 4 تا 1 ساعت در شبانهروز،

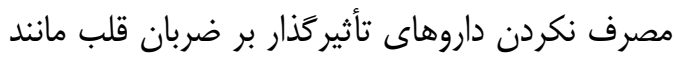

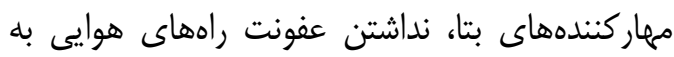

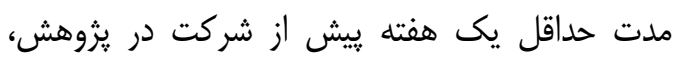
نداشتن هيجگونه بيمارى مزمنى از قبيل ديابت،

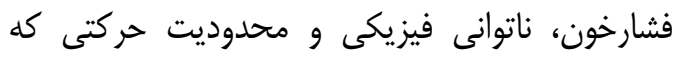

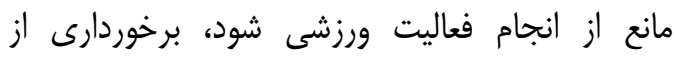
تركيب بدنى مناسب ازجمله شاخص تودها بلديت

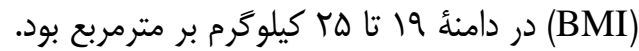
با توجه به موارد يادشده، يرسشهايى دربارئ قد و و

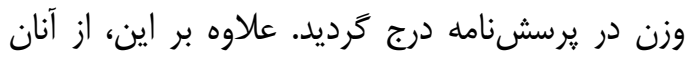

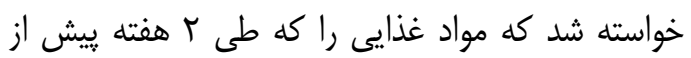
تست مصرف كردند و زمان سبرى كردن در مكانهاى مختلف را گزارش دهند. يس از جمع آورى اطلاعات

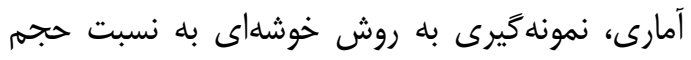

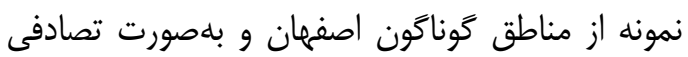

همبستخى بالايى ميان قرار كرفتن در معرض آلايندهاى هواى ناشى از ترافيك (TRAPs) و

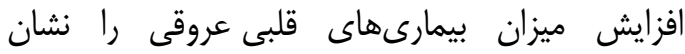

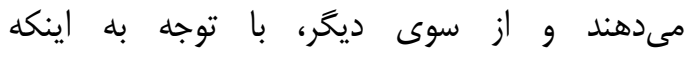

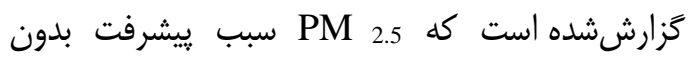
علائم آترواسكلروز در زنان يائسه مى شود؛ بنابراين به به به

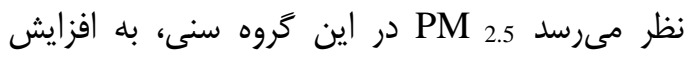

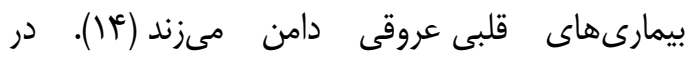

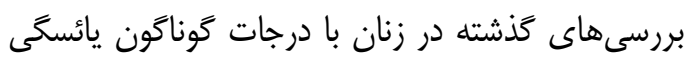
كزارش شد كه زنان ييشيائسكى تأخيرى و يائسهشده شاخصهاى گسترداى از مستعد بودن به بيمارى هاى قلبى عروقى مانند ضخيم شدن اينتيما-مديا شريان

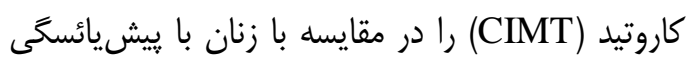

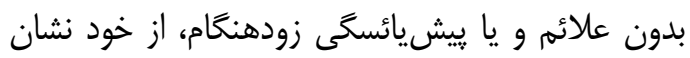

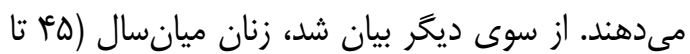

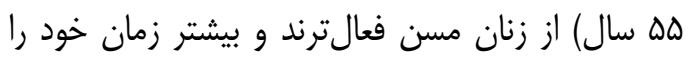

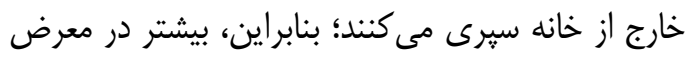

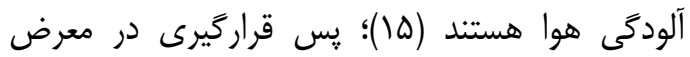

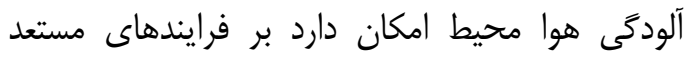

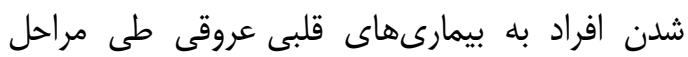

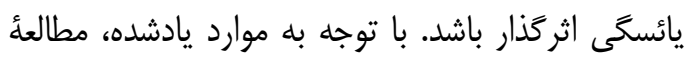

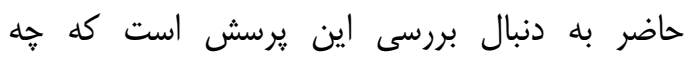
ارتباطى ميان اكسيثن مصرفى ميوكارد و يالس اكسيثن

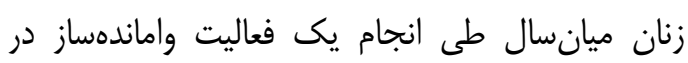

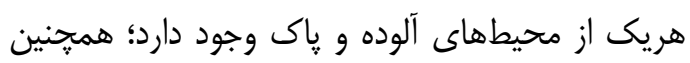
بررسى اثر آلودگى هوا بر شاخصى الودهاى قلبى عروقى

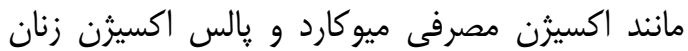
ميان سال، هدف دوم اين يزوهش است.

\section{مواد و روشان هان همان}

يروهش حاضر از نوع نيمهتجربى بود كه همأ

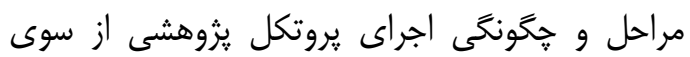

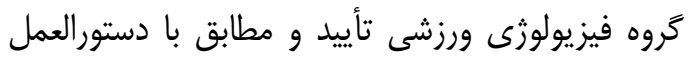
كميتأ اخلاق زيستى دانشخاه مازندران اجرا شد. بدين

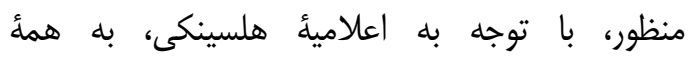
شركت كنندكان اطلاعات شفاهى و كتبى درباره هدف مطالعه ارائه كَرديد. آنان موافقتنامئ كتبى را بهاعنوان

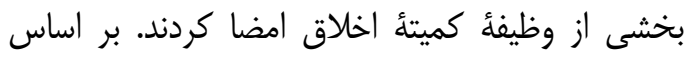

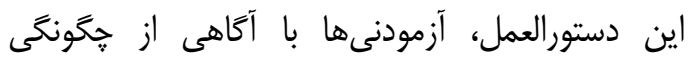


وزن و قد بر اساس توصيههاى ISAK صورت كرفت

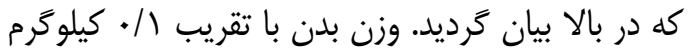

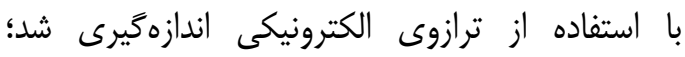

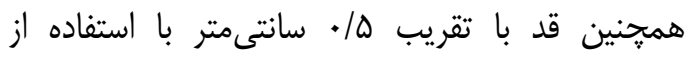

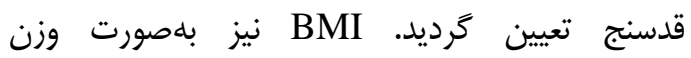
(كيلوكَرم) به مجذور قد (مترمربع) محاسبه شد.

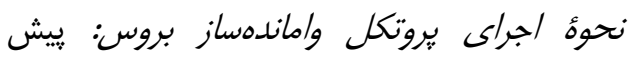

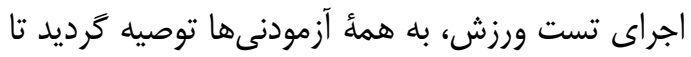
لباس و كفش راحت بيوشند و ييش از انجام آزمايش، فعاليت فيزيكى انجام ندهند. ييش ازي بإن اجراى آزمون،

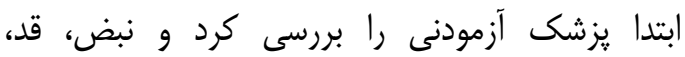

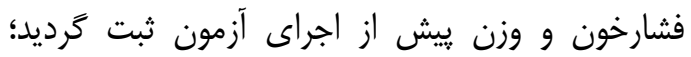

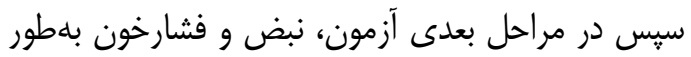

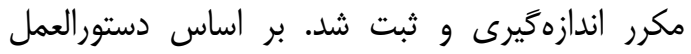

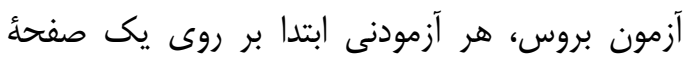

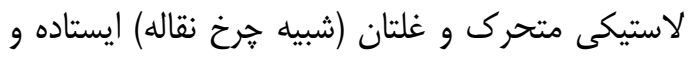
براى حفظ تعادل بايد روى آن راه برود. از آزمودنى خواسته شد كه متناسب با سرعت تسمهنقاله يا دوخرخئ مخصوص حركت كند. ابتدا دستخاه آرام حركت

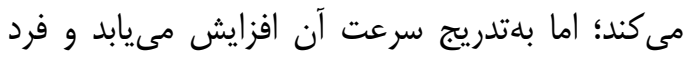
براى تداوم تست، بايد روى تسمهنقاله بدود. اين آزمون

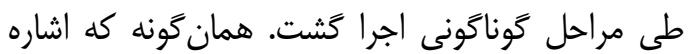

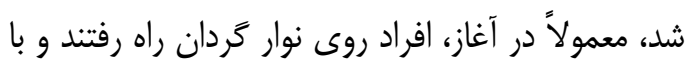
افزايش سرعت و شيب از مرحلة دوم و سوم به راه راه رفتن سريع يرداختند و در صورت توانايى براى ادامل فعاليت، شروع به دويدن كردند. هر مرحله از آزمون بروس ب دقيقه به طول مىانجامد و شيب و سرعت درون

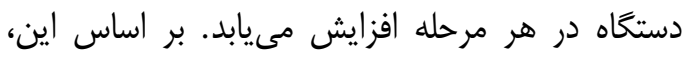

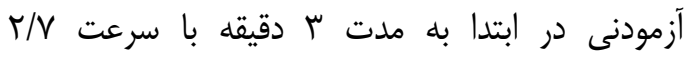

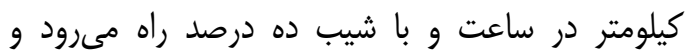
سبس در مرحلة دوم يعنى مرحلة اصلى كه خود شامل

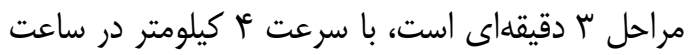

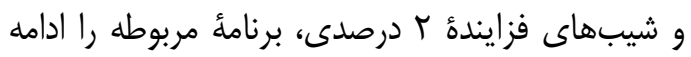

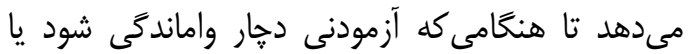
يزشك فعاليت را قطع كند (1).

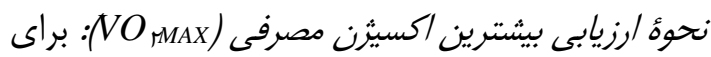
محاسبة استفاده شد (19). كفتنى است كه BMI
صورت گرفت. بر اساس اين و درمجموع، •عزن سالم با محدودة سنى هأ-هQ سال در دو گروه زنان

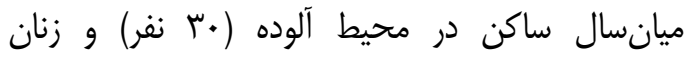

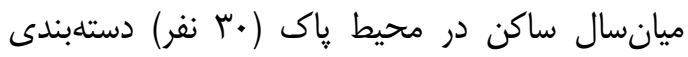
شدند.

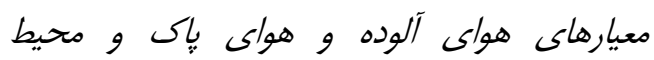

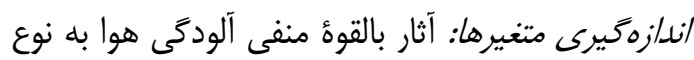

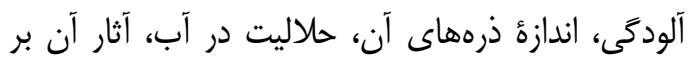

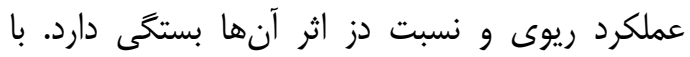
توجه به مطالعات ييشين كه در آن، افزايش مقادير آلايندههايى مانند

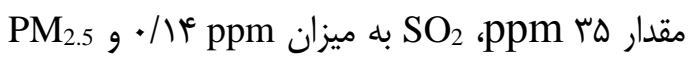
به مقدار هوا كزارش كردند (ع) كه با بروز حوادث قلبى عروقى و تنفسى همراه است، در مطالعة حاضر نيز، بر اساس

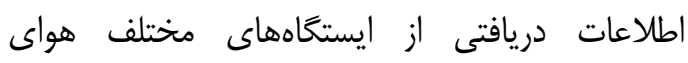
جىسىال (GCL) اصفهان در نقاط هدف، نمونه ئيرى

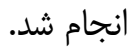
در يزوهش حاضر، اطلاعات مربوط به آلودخى هوا از طريق هماهنگى اوليه با سازمان محيطزيست استان النان

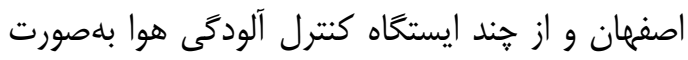

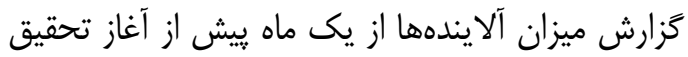

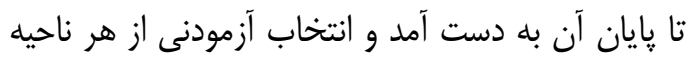

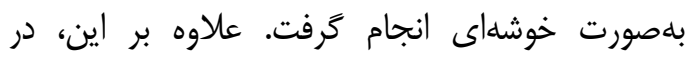
محيط انجام فعاليت ورزشى واماندهساز نيز، ميزان انجام

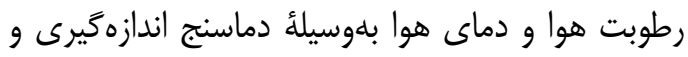

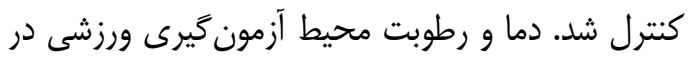

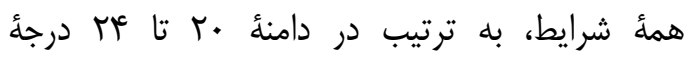

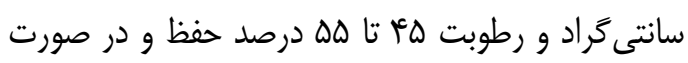
لزوم از دستخاه بخور و يا كولر اسيليت براى تنظيم دما و رطوبت استفاده گرديد. ارزيابى تركيب بلن: اندازههاى آنترويومترى در

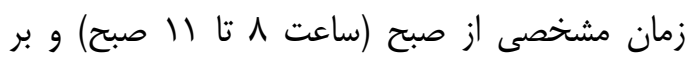
اساس توصيههاى استانداردهاى بينالمللى براى ارزيابى إنى

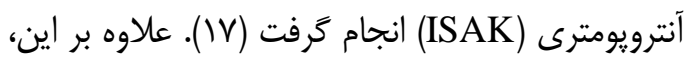

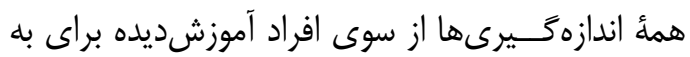

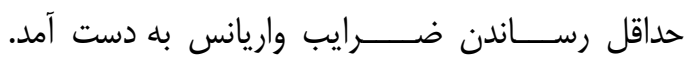
اندازهيرىها ب بار تكرار و ميانخين آنها محاسبه شد. 
نشسته و دست وى با زاوئُ •ج درجه بر روى ميز قرار كرفت و سيس اندازهيرى لازم صورت گرفت. علاوه

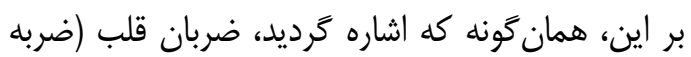
در دقيقه) در زمانهاى گَوناگون استراحتى، بلافاصله و r دقيقه پِ از فعاليت روى نوار گردان، توسط ضربانسنج (يولار ساخت فنلاند) اندازهگيرى شد.

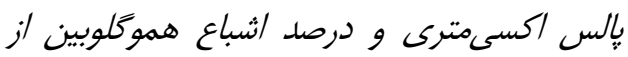

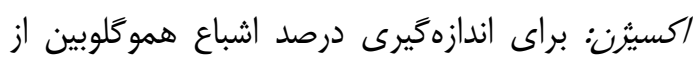

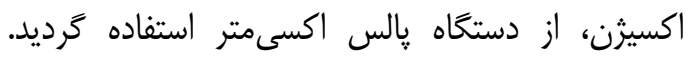

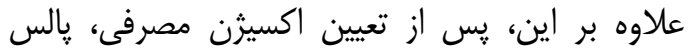
اكسيثن نيز بر اساس فرمول واسرمن و همكاران محاسبه شد (آ/). درنهايت، نسبت اكسيثن مصرفى به فيه ضربان قلب ورزشى، محاسبه و عدد مدنظر ثبت كرديد

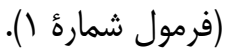

بدن، Age = سن (سال)، sex = جنسيت (مرد = ا؛ زن

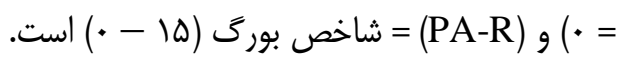

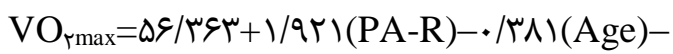
./VAF (BMI) + 1./9AV (sex).

نحوة /رزيابى اكسيثن مصرفى ميوكارد (محاسبئ

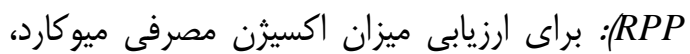

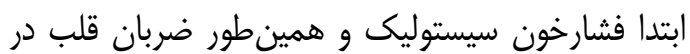

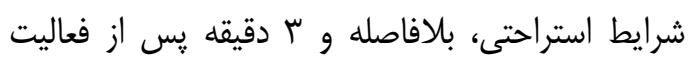

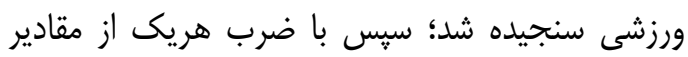

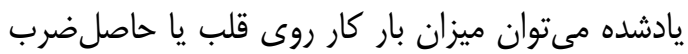

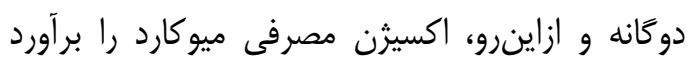

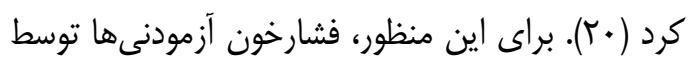

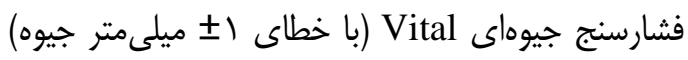
اندازهگيرى شد. براى اين كار، آزمودنى روى صندلى

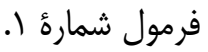

ضربان قلب ٪ اكسيثن مصرفى = يالس اكسيثن (ميلىليتر دقيقه بر كيلوگرم ضربه)

آلودכى هوا سبب تغيير معنادارى بر مقادير مدتزمان

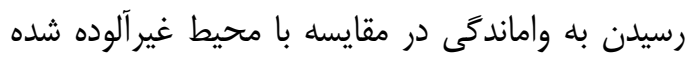

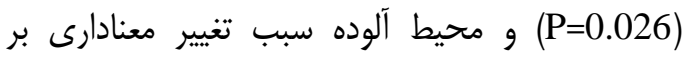

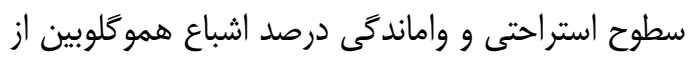
اكسيثن (SPo2) كشته است (P=0.001) (جدول

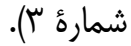
ارتباط مستقيمى ميان اكسيثن مصرفى ميوكارد و

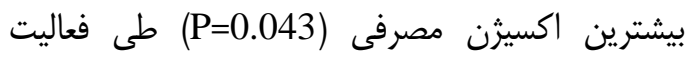

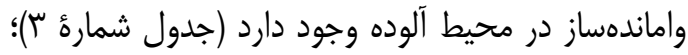
همجنين ميان فشارخون سيستوليك با اكسيثن

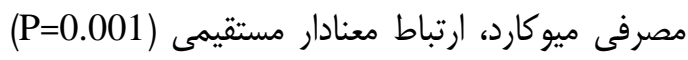

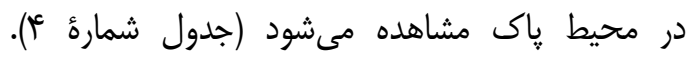
علاوه بر اين، همبستخى مثبت فراوانى ميان ضربان

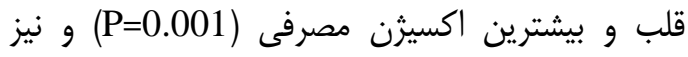
ضربان قلب و اكسيثن مصرفى ميوكارد (P=0.001) طى فعاليت واماندهساز در محيط آلوده وجود مارد دارد دارد

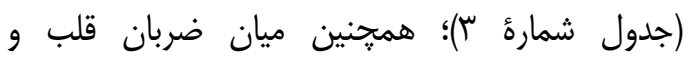
اكسيثن مصرفى ميوكارد، ارتباط تنگاتنَ مستقيمى

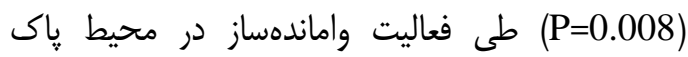
مشاهده شد (جدول شماره ع).
روش كمى و آمارى: در يزوهش حاضر، براى

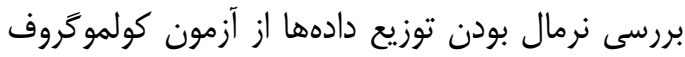

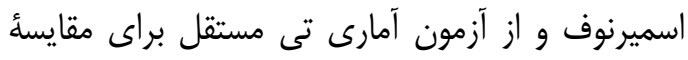

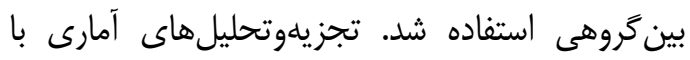

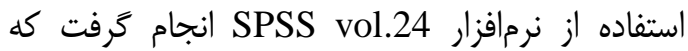
Pئح معنادارى براى همأ آزمونهاى آمارى در نظر خرفته شد.

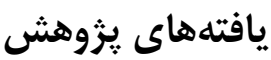

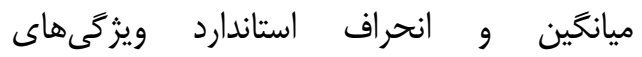
آنترويومترى مختلف در دو گروه ساكن در شهر با فحريا

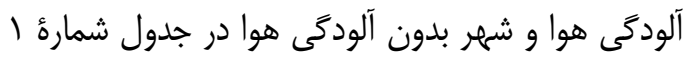

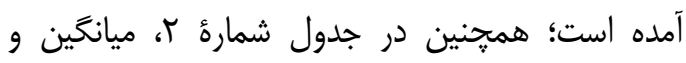

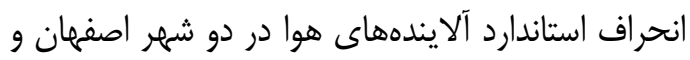

$$
\text { بابلسر زَارششده است. }
$$

آزمون تى مستقل نشان داد كه آلودَّى هوا بلهطور

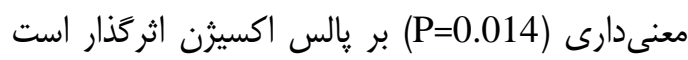

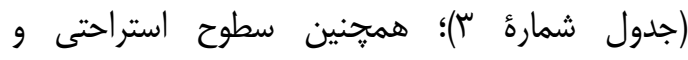
واماندگى اكسيثن مصرفى ميوكارد در هر دو گروه زنان محيط آلوده و پاك، بلهور معنادار (P=0.001) متفاوت است (جدول شماره r). علاوه بر اين، آشكار گرديد كه 
مستقيمى (P=0.001) در هر دو محيط آلوده و پاكى

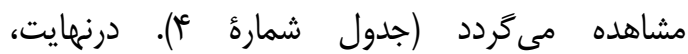
همبستگى مثبتى ميان مدتزمان فعاليت بر روى نوار

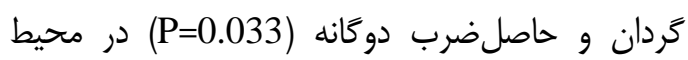
ياك ديده مى شود (جدول شماره عاء).
ارتباط مستقيمى ميان مدتزمان فعاليت بر روى

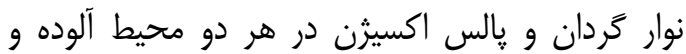

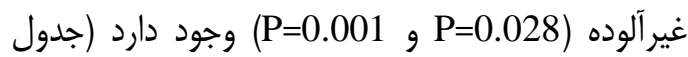

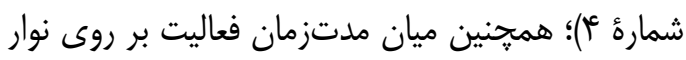

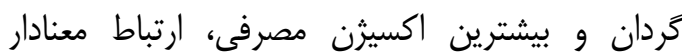

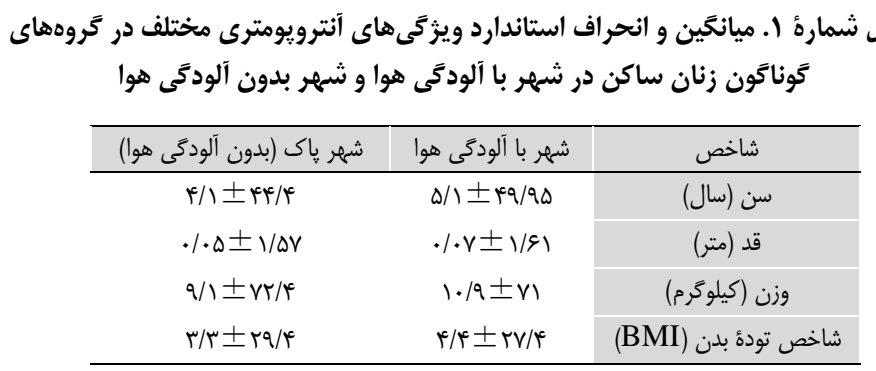

\begin{tabular}{|c|c|c|c|c|c|}
\hline$P$ & انحراف استاندارد & ميانكَين & تعداد روزها & شهر & \\
\hline \multirow{2}{*}{$<0.001$} & $r_{\Delta}$ & $\Lambda \Delta$ & IVA & اصفهان" & \multirow[t]{2}{*}{$\mathrm{AQ}_{\mathrm{I}}$} \\
\hline & r & rq & $1 \wedge$. & بابلسرب & \\
\hline \multirow[t]{2}{*}{$<0.001$} & $\mid r / c$ & $r \Delta / r$ & IVA & اصفهان & \multirow[t]{2}{*}{$\mathrm{SO}_{2}$} \\
\hline & . & . & १. & بابلسر & \\
\hline \multirow[t]{2}{*}{$<0.001$} & rr & $\Lambda / \mu$ & IVA & اصفهان & \multirow[t]{2}{*}{$\mathrm{PM}_{2.5}$} \\
\hline & . & . & 14. & بابلسر ب بار & \\
\hline
\end{tabular}

جدول شمارهُ با. ميانكين و انحر اف استاندارد شاخص هاى اكسيثن مصرفى ميوكارد و يالس اكسيثن

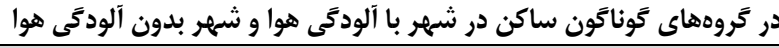

\begin{tabular}{|c|c|c|c|c|}
\hline \multicolumn{4}{|c|}{ محيط } & \multirow[t]{3}{*}{ شاخص مرحلة آزمون } \\
\hline \multicolumn{2}{|c|}{ لياك } & \multicolumn{2}{|c|}{ آلوده } & \\
\hline 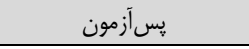 & ي يِشآزمون & 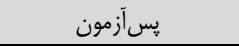 & ي ي & \\
\hline$\# \neq$ rYVN/V \pm rVT/Tr & $\neq V \Delta T / \cdot r \pm I Q N / F r$ & $\# r r \cdot q / q \Delta \pm r \Delta r / q q$ & $901 / \Lambda \pm 101 / / r$ & $\begin{array}{c}\text { RPP } \\
\text { (ميلى متر جيوه در ضربه بر دقيقه) }\end{array}$ \\
\hline$\neq . / 9 \Lambda \pm . / .1$ & $\neq . / 9 \wedge \pm . / \cdot 1$ & $\cdot 198 \pm \cdot / \cdot 1$ & $\cdot / 9 \Delta \pm \cdot 1 \cdot \cdot \Delta$ & $\begin{array}{l}\mathrm{SPo} 2 \\
(\nu, د)\end{array}$ \\
\hline \multicolumn{2}{|c|}{$\neq \cdot / 19 \mu r \pm \cdot . \cdot 194$} & \multicolumn{2}{|c|}{$\cdot / 1 \cdot 9 \pm \cdot / \cdot 11 \mathrm{~V}$} & $\begin{array}{c}\text { Pulse O2 } \\
\text { (ميلى ليتر /كيلوكرم. ضربه) }\end{array}$ \\
\hline \multicolumn{2}{|c|}{$\neq \vee / \wedge \varepsilon \pm 1 / \& q \uparrow$} & \multicolumn{2}{|c|}{$q / T r) \pm r / r q$} & مدتزمان فعاليت بر روى نوار گردان \\
\hline \multicolumn{2}{|c|}{$r r / V \pm r / \Delta r$} & \multicolumn{2}{|c|}{ عس/r } & بيشترين اكسيثن مصرفى \\
\hline
\end{tabular}

نشانهُ معنادارى نسبت به وضعيت مشابه در محيط آلوده\# نشانهُ معنادارى نسبت به وضعيت استراحتى؛ 
جدول شماره f. همبستخى و ارتباط شاخصهاى كَناتَون با يالس اكسيزن و بيشترين اكسيزن مصرفى در هر دو تروه

\begin{tabular}{|c|c|c|c|c|c|c|c|}
\hline \multicolumn{3}{|c|}{ محيط پاى } & \multicolumn{3}{|c|}{ محيط آلوده } & \multirow{2}{*}{\multicolumn{2}{|c|}{ شاخص }} \\
\hline RPP & $\mathrm{VO} 2_{\max }$ & Pulse $\mathrm{O}_{2}$ & RPP & $\mathrm{VO} 2_{\text {max }}$ & Pulse $\mathrm{O}_{2}$ & & \\
\hline & .1 .90 & -.1 .94 & & $* / \pi q 9$ & 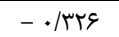 & $\mathrm{r}$ & RPP \\
\hline & . & 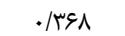 & & 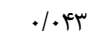 & $.1 \cdot 1$ & $\mathrm{P}$ & \\
\hline$* * / V \uparrow \&$ & 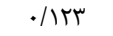 & . Tצ9 & . /MAV & 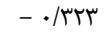 & $.1 .1 \mathrm{~V}$ & $\mathrm{r}$ & فشارخون سيستوليك \\
\hline $.1 . .1$ &.$/ T \Delta Q$ & $.1 . \mathrm{W}$ & $. / T / Q$ &.$/ . \wedge \mu$ &.$/$ LVt & $\mathrm{P}$ & (ميلىمتر جيوه) \\
\hline$* * / 4 F$ &.$- / \cdot r \Delta$ & $-\cdot / \mu \cdot \mu$ & $* * / V G$ & $* * \cdot 94 \mid$ &.$- / 199$ & $\mathrm{r}$ & ضربان قلب \\
\hline$\cdot 1 \cdot 1$ & 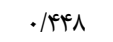 &.$/ \Delta T$ & $.1 . .1$ & $.1 . .1$ & גזוא. & $\mathrm{P}$ & (ضربه بر دقيقه) \\
\hline . MYA & $-\cdot / T Y A$ & $-. / M+1$ &.$/ \mathrm{AV}$ & ع &.$/ T M A$ & $\mathrm{r}$ & SPo2 \\
\hline $.1 .9 \pi$ & . & .1 .99 & $\cdot / T I \Delta$ & .1 .09 & .11 .9 & $\mathrm{P}$ & \\
\hline.$/ N{ }^{2}$ & $* * / M F$ & $* * / V \wedge \varphi$ & $\% \cdot / 419$ & **** $\cdot 9 \cdot \varphi^{c}$ & 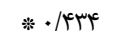 & $\mathrm{r}$ & مدتزمان فعاليت بر روى نوار گردان \\
\hline.$/ 1 \mathrm{~A}$ &.$/ .+1$ &.$/ . .1$ & 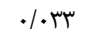 & $.1 . .1$ &.$/ . \mathrm{r \Lambda}$ & $\mathrm{P}$ & (دقيقه) \\
\hline
\end{tabular}

شاخص زيستى زودهنگًام عملكرد اندوتليال دانست كه

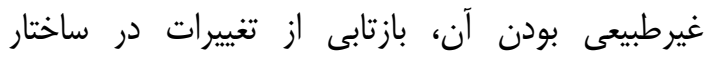

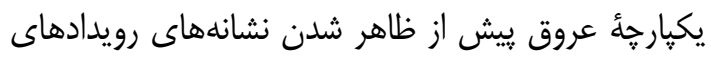

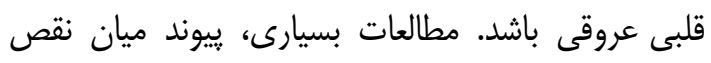

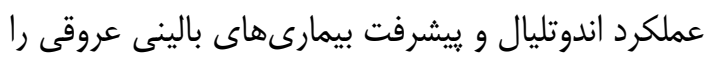
نشان مىدهند (Tr).

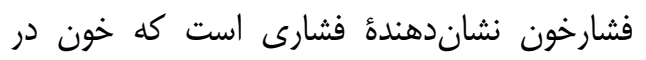
سيستم گردش خود ايجاد مى كند. ازآنجاكه فشارخون

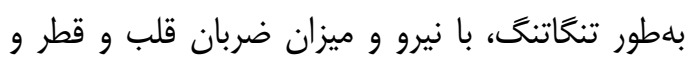

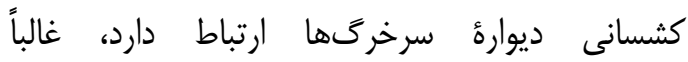
اندازهيرى مىشود (ه). كزارش شده است كه فشارخون

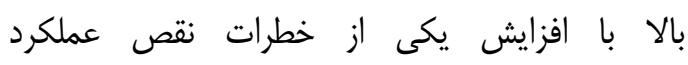

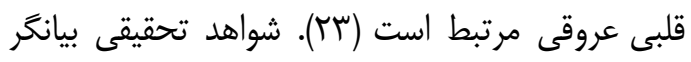
آن است كه ازن مىتواند بر قطر و تون مونط مويركى اثر

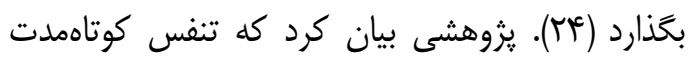

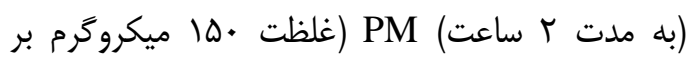

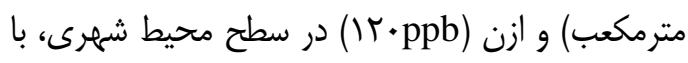

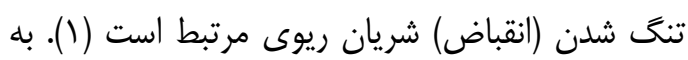
علت همبستخى ميان واكنشيذيرى شريان كرونرى و

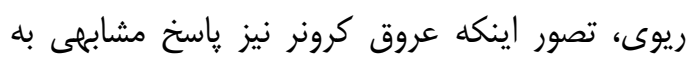
آلودگى هوا دهد، منطقى است. تصور اينها عروق كرون

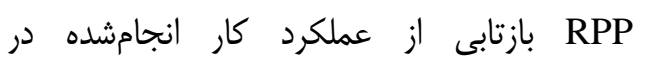

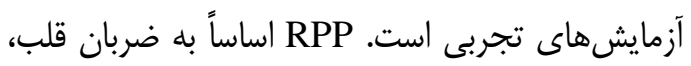

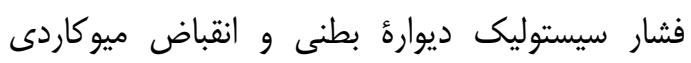

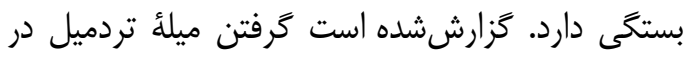

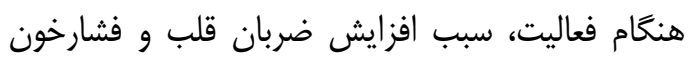

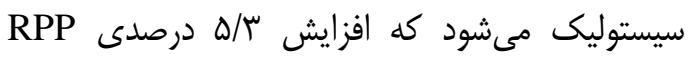

بحث و نتيجل كيرى

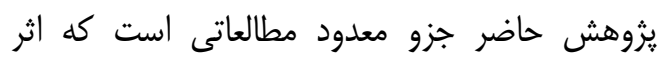
آيندههاى هوا را در زنان با سنين بالا طى دوره قرو مراركيرى

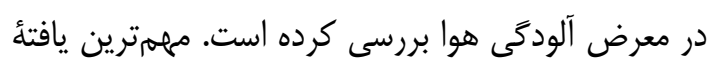
يزوهش حاضر آن است كه آلودگى هوا بر شاخص هرداى

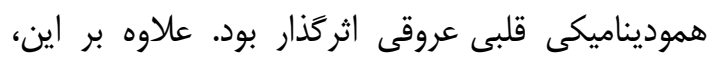

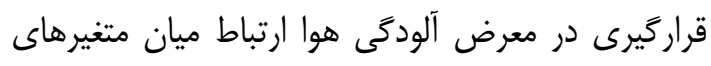

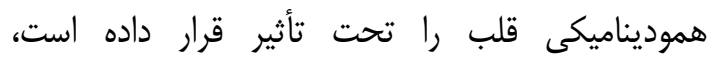
بلكَونهاى كه ميان اكسيثن مصرفى ميوكارد و بيشترين اكسيثن مصرفى طى فعاليت واماندهساز در محيط آلودهن،

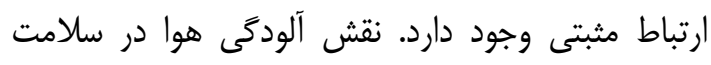

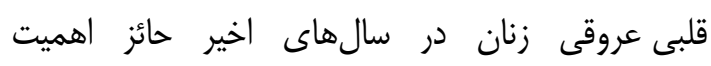

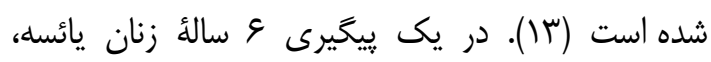

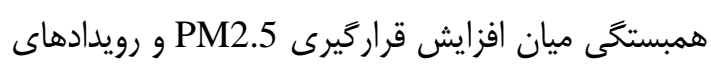

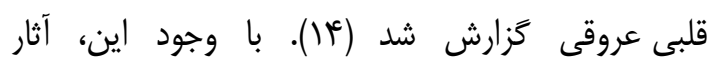

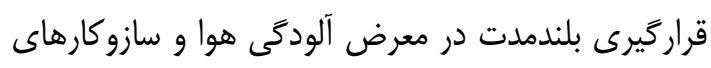
آن در بروز بيمارىهاى قلبى عروقى آشكار نيست؛ اما

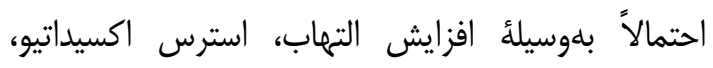

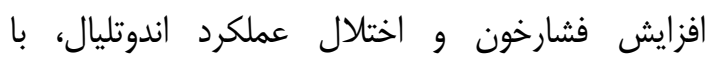
آترواسكلروز ارتباط دارد (س) (1).

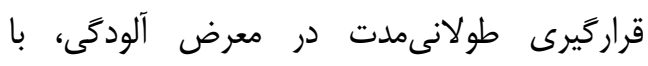

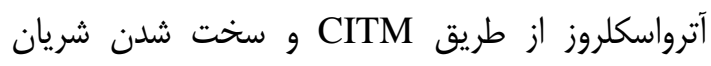

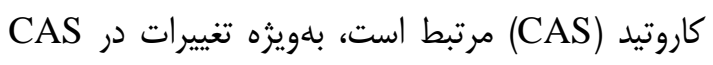

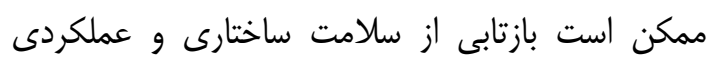

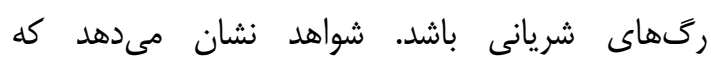
فشارخون و CAS ارتباط بسيار مستقيمى با خطرات

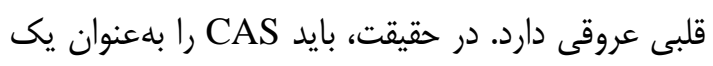


ميوكاردى و كاهش جريان خون كرونرى را به همراه دارد (9).) در مطالعات ييشين، ارتباط جشمخيرى ميان قراركيرى كوتاهمدت در معرض PM

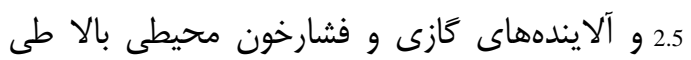
محدودهاى از غلظت اين آلايندهها را كزارش دادئل

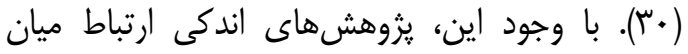

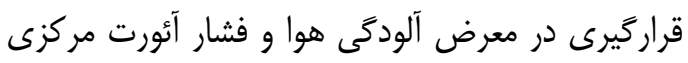

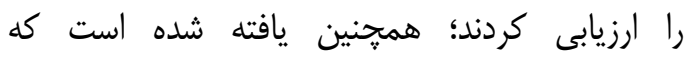

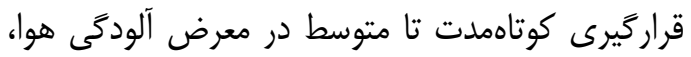
با افزايش ڤِبار بطن جֶ (CASP و CADP) و طولانى شدن دورة انقباض ديواره بطنى (ED) در

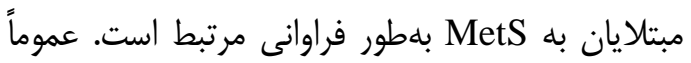
قرارگيرى كوتاهمدت تا متوسط در معرض PM2.5، PM10 و SO2 با كاهش SEVR و قرارگيرى در

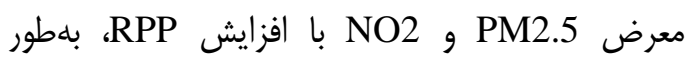
جشمخيرى ارتباط دارد (َّ).

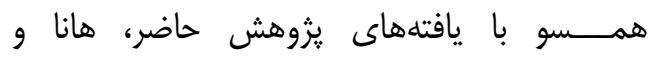

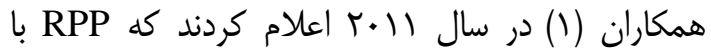
دورة هِنسنى (ED)، بازتابى از دورة سيستوليك بطنى و

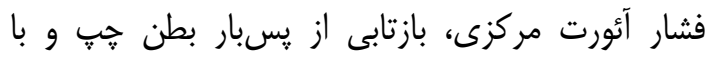

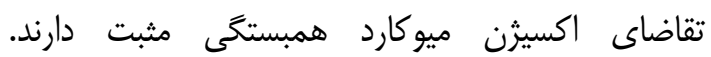
مطالعات مربوط به اثر قراركيرى كنترلشده بر ذرات متمركز محيطى (CAPs) بهطور آشكار نشان مى مدهند

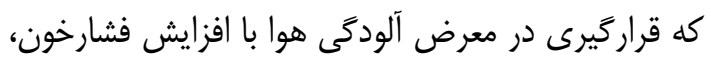

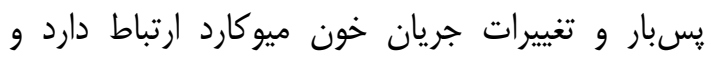
تشديدكننده يا عامل بالقوه ينهانى ايسكيمى خواهد بودات

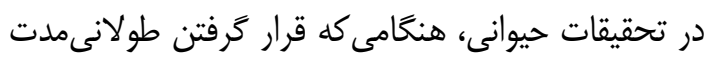

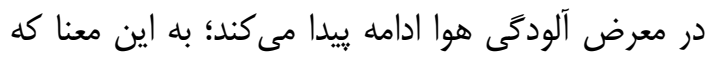
از محدوده عمر جوندكان بيشتر شود، تغيير ذخيرؤ جريان كرونرى، هاييرتروفى قلبى، ريمدلينگ ميوكارد، فيبروز و

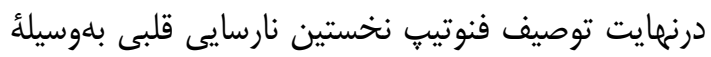

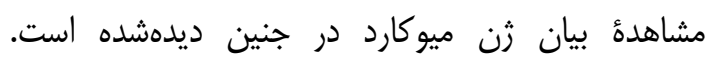

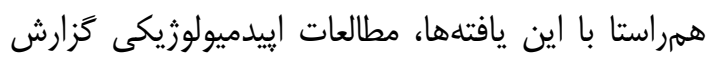
دادند كه قرارگيرى در معرض آلودگى هوا با رويدادهاى ائي

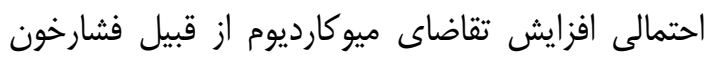

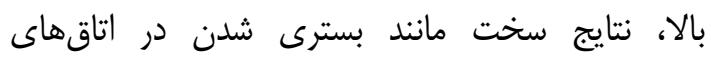
اورزانس و بسترى شدن در بيمارستان به علت فشارخون
بيشينه را در يى دارد (مه). اين در حالى است كه طى يك تست ورزش، تغييرات ريكاورى يس إز تمرين

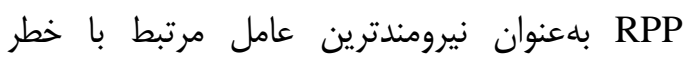

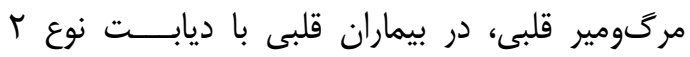

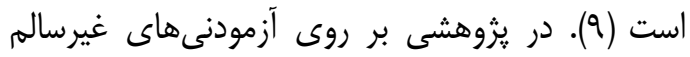

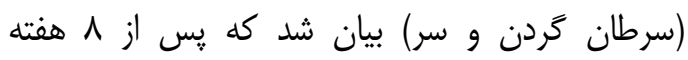
تمرين ورزشى، پاسخهاى قلبى عروقى فيزيولوزيكى از

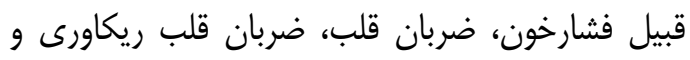

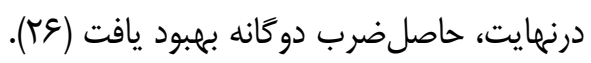

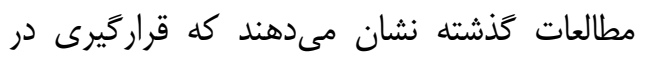
معرض آلودگى هواى محيط، با اختلال در مؤلفههاى

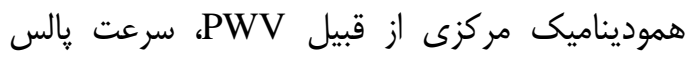

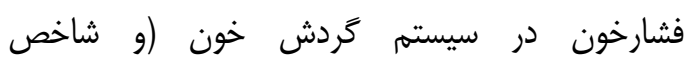

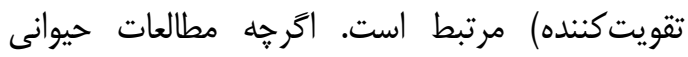

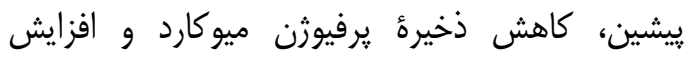

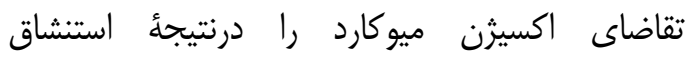
مونوكسيد كربن يا CAPs را نشان دادند؛ اما هيجَّونه

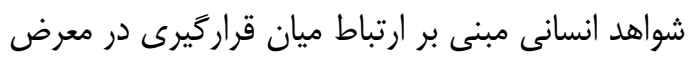

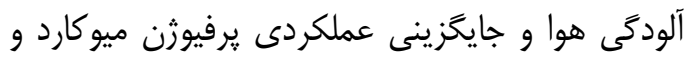

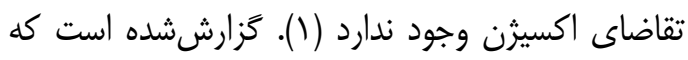

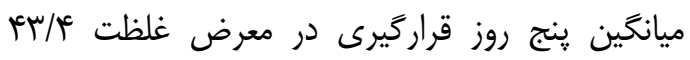

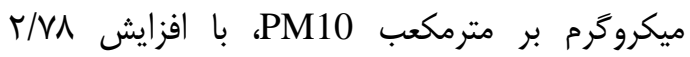

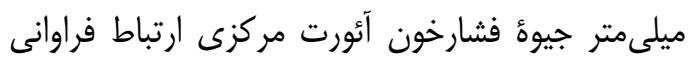

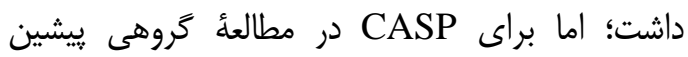

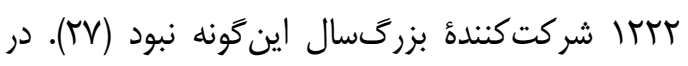
شواهد حيوانى، قرارگيرى در معرض مونواكسيد كربن

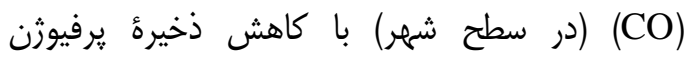
ميوكارد، از طريق اختلال در وازوريلكسيشن (كاهش بانش

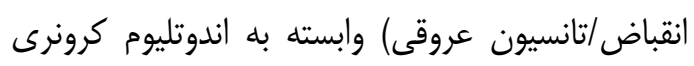

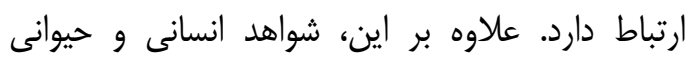

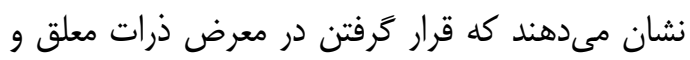
كربن، افزايش فشارخون شريانى را به دنبال دارد (rᄉ)

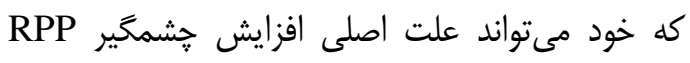

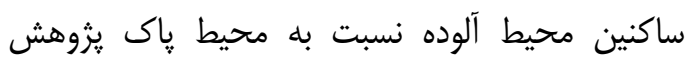

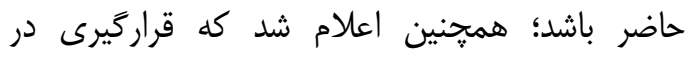

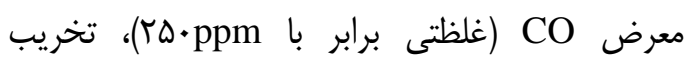
استفادة اكسيثن قلبى بلوسيلة افزايش تقاضاى اكسيثن 
مصرفى ميوكارد را نشان داد، بdگونهاى كه قرارگيرى در معرض آلودخى هوا و همينطور اجراى فعاليت واماندهساز در اين گونه محيطها، بار وارده بر قلب و اكسيثن مصرفى ميوكارد را افزايش مىدهد. در همين راستا، در مطالعئ حاضر آشكار شد ارتباط مستقيمى ميان اكسيثن مصرفى مئى ميوكارد و بيشترين اكسيزن مصرفى در زنان ميانسال،

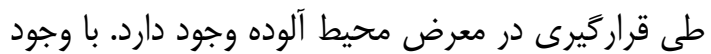
اين، يزوهش حاضر با محدوديتهايى مانند نبودِ

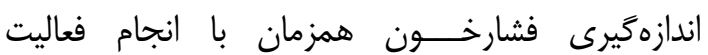
واماندهساز و بررسى تغييرات آن حين فعاليت، نسنجيدن

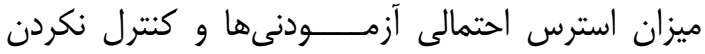
كامل رزيم غذايى افراد مواجـــــه بوده است؛ بنابراين إسن توصيه مىشود كه در مطالعات آتى، موارد يادشده كنترل گردند تا بدين طريق به گَشهاى از ابهامات پاسخ داده

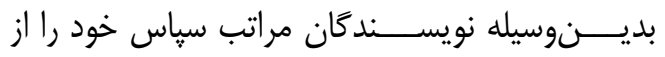

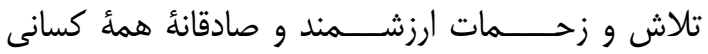

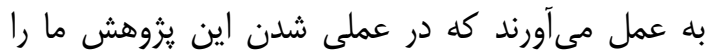
يارى كردند. كد /خلاق:

\section{References}

1.Hanna AF, Yeatts KB, Xiu A, Zhu Z, Smith RL, Davis NN, et al. Associations between ozone and morbidity using the spatial synoptic classification system. Environ Health 2011;10:49. doi.10.1186/1476-069X-10-49

2.Srebot V, Gianicolo EA, Rainaldi G, Trivella MG, Sicari R. Ozone and cardiovascular injury. Cardiovas Ult2009;7:1-8. doi.10.1186/1476-7120-730

3.Sarnat SE, Suh HH, Coull BA, Schwartz J, Stone PH, Gold DR. Ambient particulate air pollution and cardiac arrhythmia in a panel of older adults in Steubenville, Ohio. Occup Environ Med2006;63:700-6. doi.10.1136/oem.2006.027292

4.Liu S, Brook RD, Huang W, Fan Z, Xu $\mathrm{H}, \mathrm{Wu} \mathrm{R}$, et al. Extreme levels of ambient air pollution adversely impact cardiac and central aortic hemodynamics: the AIRCMD China study. J Am Soc Hyp2017;11:75461. doi.10.1016/j.jash.2017.09.009
بالا و درنهايت ييامدهاى ناشى از افزايش فشارخون مانند بسترى شدن در بيمارستان به سبب نارسايى قلبى در ارتباط است (ب).

شرايط آبوهوايى و جوى مىتواند بر سطح قرار گرفتن در معرض آلايندهها و گياسخ فيزيولوزيكى اثر بحذارد؛ همجنين مدتزمان سيرى كردن و تمرين كردن در محيط آلوده نيز بر ميزان بيامدها مؤثر است (أl)؛ بنابراين توصيه مىشود كه افراد تا حد امكان از ورزش در مر مرير محيط با آلودگى هوا و ترافيك بيرهيزند. بايد اذعان داشت كاهش ميزان غلظت بسيارى از آلايندههاى هوا با افزايش فاصله از جاده مرتبط است و ازاينرو، افراد در منازل، فضاهاى باز بيرون شهرها و يا ياركها به ورزش

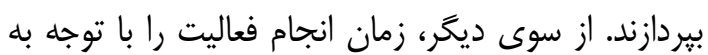
زمان اوج ميزان آلايندهها تنظيه و برنامهريزى كرد؛ به اين معنا كه در ساعات شلوغى به علت تجمع اكسيدهاى ازت (NOx)، كربن مونوكسيد (COx) و تركيبات آلى فرار

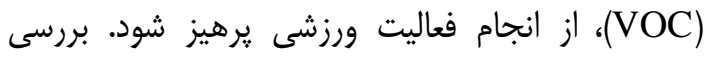
ييشبينىهاى آلودگى هوا و ييروى كردن از هشدارها مىتواند دراينباره كارآمد باشد.

يافتههاى يزوهش حاضر بار ديخر تأثير آلودگى هوا

بر مؤلفههاى هموديناميكى قلبى عروقى، بلويزه اكسيزن

5.Baumgartner J, Carter E, Schauer JJ, Ezzati M, Daskalopoulou SS, Valois M-F, et al. Household air pollution and measures of blood pressure, arterial stiffness and central haemodynamics. Heart 2018;104:1515-21.doi.10.1136/heartjnl2017-312595

6.Golshahi J, Sadeghi M, Zavar R, Sadeghifar M, Roohafza H. Exposure to occupational air pollution and cardiac function in workers of the Esfahan steel industry Iran. Environ Sci Poll Res2016;23:11759-65. doi.10.1007/s11356016-6334-9

7.Pun VC, Ho Kf. Blood pressure and pulmonary health effects of ozone and black carbon exposure in young adult runners. Sci Tot Environ 2019;657:1-6. doi.10.1016/j.scitotenv.2018.11.465

8.Zanobetti A, Canner MJ, Stone PH, Schwartz J, Sher D, Eagan E, et al. Ambient pollution and blood pressure in 
cardiac rehabilitation patients. Circulation 2004;110:2184-9.

9.Kiviniemi AM, Kentta TV, Lepojarvi S, Perkiömäki JS, Piira OP, Ukkola O, et al. Recovery of rate pressure product and cardiac mortality in coronary artery disease patients with type 2 diabetes. Diabet Res Clin Pract2019;150:150-7. doi.10.1016/j.diabres.2019.03.007

10.Bhatia S, Sood A. Obesity and obstructive lung disease an epidemiologic review. Mech Manifest Obesit Lung Dis 2019;2: 67-87. doi.10.1016/B978-0-12813553-2.00004-X

11.Honorato O,, Pedro M, Oscar, Francisco F. Effects of 8 weeks concurrent strength and aerobic training on body composition physiological and cognitive performance in older adult Women. Sustainability 2020, 12, 1944; doi.10.3390/su12051944

12.Lee K, Sener IN. Understanding potential exposure of bicyclists on roadways to traffic-related air pollution findings from el paso texas, using strava metro data. Int $\mathbf{J}$ Environ Res Publ Health2019;16:371.

doi.10.3390/ijerph16030371

13.Tainio M, de Nazelle AJ, Götschi T, Kahlmeier S, Rojas-Rueda D, Nieuwenhuijsen MJ, et al. Can air pollution negate the health benefits of cycling and walking? Preve Med2016;87:233-6. doi.10.1016/j.ypmed.2016.02.002

14.Franklin M, Zeka A, Schwartz J. Association between PM 2.5 and all-cause and specific-cause mortality in 27 US communities. J Exp Sci Environ Epidemiol2007;17:279-87.

doi.10.1038/sj.jes.7500530

15.Elkhoudary SR, Wildman RP, Matthews K, Thurston RC, Bromberger JT, Sutton K. Progression rates of carotid intima media thickness and adventitial diameter during the menopausal transition. Menopause 2013;20:8.

doi.10.1097/gme.0b013e3182611787

16. Roberts S, Robergs R. Fundamental principles of exercise physiology for fitness performance and health essentials of strength training and conditioning. 1 th $\mathrm{ed}$. Mcgraw Hill Publication. 2000;P.123.

17.Ellis KJ, Bell SJ, Chertow GM, Chumlea WC, Knox TA, Kotler DP, et al. Bioelectrical impedance methods in clinical research a follow up to the NIH technology assessment

conference.

Nutrition1999;15:874-80.

doi.10.1016/S0899-9007(99)00147-1

18. Wessel HU, Strasburger JF, Mitchell

BM. New standards for the Bruce treadmill

protocol in children and adolescents.

Pediatr Exe Sci 2001;13:392-401.

doi.10.1123/pes.13.4.392

19.Strom CJ, Pettitt RW, Krynski LM, Jamnick NA, Hein CJ, Pettitt CD. Validity of a customized submaximal treadmill protocol for determining VO 2max. European J Appl Physiol2018;118:1781-7. doi.10.1007/s00421-018-3908-x

20.Smith DL, Fernhall B. Advanced cardiovascular exercise physiology: Human Kinetics; 2011.

21.Wasserman K, Hansen JE, Sue DY, Whipp BJ, Froelicher VF. Principles of exercise testing and interpretation. $\mathbf{J}$ Cardiopulmonar Rehabil Preve1987;7:189.

22.Breton CV, Mack WJ, Yao J, Berhane K, Amadeus M, Lurmann F, et al. Prenatal air pollution exposure and early cardiovascular phenotypes in young adults. Plos One2016;11:0150825. doi.10.1371/journal.pone.015082

23.Williams B, Poulter N, Brown M, Davis M, McInnes G, Potter J, et al. Guidelines for management of hypertension: report of the fourth working party of the British Hypertension Society, 2004-BHS IV. J Hum Hyp2004;18:139-85. Doi:10.1038/sj.jhh.1001683

24.Brook RD, Brook JR, Urch B, Vincent R, Rajagopalan S, Silverman F. Inhalation of fine particulate air pollution and ozone causes acute arterial vasoconstriction in healthy adults. Circulation 2002;105:15346. doi.10.1161/01.cir.0000013838.94747.64 25. Whitman M, Sabapathy S, Jenkins C, Adams L. Handrail support produces a higher rate pressure product in apparently healthy non-treadmill users during maximal exercise testing. Physiol Measure2019;40: 2. doi.10.1016/j.hlc.2018.06.613

26. Yen CJ, Hung CH, Kao CL, Tsai WM, Chan $\mathrm{SH}$, Cheng $\mathrm{HC}$, et al. Multimodal exercise ameliorates exercise responses and body composition in head and neck cancer patients receiving chemotherapy. Sup Care Cancer2019;27:4687-95. doi. 10.1007/s00520-019-04786-1

27.Adamopoulos D, Vyssoulis G, Karpanou E, Kyvelou SM, Argacha JF, Cokkinos D, 
et al. Environmental determinants of blood pressure, arterial stiffness, and central hemodynamics. J Hyp2010;28:903-9. doi.10.1097/hjh.0b013e3283369f67

28.Pun VC, Ho KF. Blood pressure and pulmonary health effects of ozone and black carbon exposure in young adult runners. Sci Total Environ 2019; 20;657:16. doi.10.1016/j.scitotenv.2018.11.465

29.Favory R, Lancel S, Tissier S, Mathieu $\mathrm{D}$, Decoster B, Nevière R. Myocardial dysfunction and potential cardiac hypoxia in rats induced by carbon monoxide inhalation. American J Res Crit Care Med2006;174:320-5. doi.10.1164/rccm.200601-117oc 30.Brook RD, Sun Z, Brook JR, Zhao X, Ruan Y, Yan J, et al. Extreme air pollution conditions adversely affect blood pressure and insulin resistance: the air pollution and cardiometabolic disease study. Hypertension 2016;67:77-85. doi.10.1161/hypertensionaha.115.06237 


\title{
Correlation between Cardiovascular Hemodynamic Parameters of Perimenopausal Women during an Exhaustive Activity at Air Polluted and Non-Air-Polluted Environments
}

\author{
Pouriamehr $S^{1}$, Dabidiroshan $V^{* 1}$, Shirani $F^{2}$
}

(Received: November 8, 2020

\begin{abstract}
Introduction: Air pollution is the main factor and modulation of cardiovascular diseases in urban societies. The potentially harmful effects of acute and chronic air pollution exposure have serious consequences on disease and mortality. This study amid to investigate the correlation between cardiovascular hemodynamic parameters of perimenopausal women during an exhaustive activity in air polluted and nonair polluted environments.
\end{abstract}

Materials \& Methods: This semiexperimental study randomly investigated 60 women (age range: 46.62 years; body mass index: 28.57 \pm 3.85 ) at the perimenopausal stage who were living in an air polluted environment $(n=30$ in the experimental group) and non-air polluted environment ( $\mathrm{n}=30$ in the control group). Furthermore, different cardiovascular hemodynamic parameters were evaluated before and after the Bruce test as an exhaustive activity.
Accepted: February 6, 2021)

Ethics code: Ir.umz.rec.1397.019

Findings: There is a direct correlation between myocardial oxygen consumption and maximal oxygen consumption $(\mathrm{P}<0.05)$ during an exhaustive activity in the air polluted environment. Moreover, the independent $\mathrm{t}$-test showed that air pollution significantly affected the pulse of oxygen $(\mathrm{P}<0.05)$.

Discussions \& Conclusions: The findings of this study have shown the air pollution effects on cardiovascular hemodynamic parameters, particularly myocardial oxygen consumption. In addition, it was found that air pollution exposure and performing an exhaustive activity in such environments would increase the cardio workload and the myocardial oxygen consumption.

Keywords: Air pollution, Exhaustive activity, Myocardial oxygen consumption, Perimenopausal, pulse oxygen

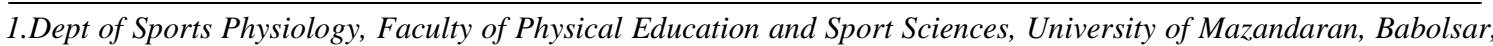
Iran.

2.Cardiovascular Rehabilitation Research Center, Cardiovascular Research Institute, Esfahan Medical Science University, Esfahan, Iran

*Corresponding author Email: vdabidiroshan@yahoo.com

Scientific Journal of Ilam University of Medical Sciences 